Article

\title{
How State Interventions affect Municipalities Taking the Lead in Sustainability
}

\author{
Jayce L. Farmer *(D) and Andres J. Rodriguez Lombeida
}

School of Public Policy and Leadership, University of Nevada, Las Vegas, NV 89154-4030, USA; rodria49@unlv.nevada.edu

* Correspondence: jayce.farmer@unlv.edu

\begin{abstract}
The state and local governments throughout the United States interact within a complex system of multilevel governance to advance sustainability. However, we know little about what this hierarchical system of exchanges means for municipalities as they work to achieve energy efficient government operations. Drawing on a perspective of "contested federalism", we examine how the transaction costs of state-local government relations affect the efforts of U.S. cities to lead by example and promote sustainability within their internal processes. We apply a Bayesian item response theory approach to assess the effects of state-level fiscal and policy interventions on municipal commitments to energy efficiency programs within their internal operations. Our findings suggest that increased fiscal support for state energy programs enhances municipal commitments to government focused energy efficiency. We also find a positive connection between state energy efficiency standards and municipal efforts to enhance energy efficiency within their internal operations. The alignment of state resources and policy efforts with municipal actions can reduce commitment and agency costs that obstruct policy outcomes. The findings speak to the importance of multilevel governance exchanges in municipal efforts to become leaders in sustainability.
\end{abstract}

Citation: Farmer, J.L.; Rodriguez

Lombeida, A.J. How State

Interventions affect Municipalities Taking the Lead in Sustainability. Sustainability 2021, 13, 6479. https:// doi.org/10.3390/su13116479

Academic Editor: Gerardo Maria Mauro

Received: 5 May 2021

Accepted: 30 May 2021

Published: 7 June 2021

Publisher's Note: MDPI stays neutral with regard to jurisdictional claims in published maps and institutional affiliations.
Keywords: municipal sustainability; energy efficiency; leading by example programs; sustainable energy policies

\section{Introduction}

U.S. state and local governments often interact to promote environmental sustainability within a complex system based upon multilevel governance exchanges. This hierarchical state-local government relationship is one based upon regulation, cooperation, and transactions, where actors either coordinate or collide around policy issues [1]. Within this relationship, states through their laws and fiscal involvement have been shown to play a vital role in municipal government sustainability actions $[2,3]$.

While state governments are known for shaping sustainability policy initiatives [4,5], city governments are increasingly taking steps to advance sustainability by promoting energy efficiency in their own everyday processes [6]. This practice, commonly referred to as "Leading by Example" (LBE), involves municipalities taking actions to improve energy efficiency within government facilities, fleets, and operations [5]. However, theory and empirical study of state and local relations around sustainability do not adequately account for the role of state-level intervention in municipal endeavors to take the lead in sustainability issues $[2-4,7,8]$. This is an important scholarly omission since the flows of resources and authority from the states can influence local government policy execution. Thus, the abilities of local governments to pursue policy outcomes can be greatly affected by their state environments $[9,10]$.

This article begins to fill this gap in understanding by asking: What are the effects of state intervention on municipal commitments to LBE? We address this question by drawing upon a theoretical lens of "contested federalism" that explains how political transaction costs can shape how state institutions facilitate or impede municipal sustainability 
actions $[1,11]$. From this perspective, the competing goals and incentives of state and local governments can lead to policy misalignments that give rise to distinct commitment, agency, and administrative costs. These transaction costs can lead to policy impediments that obstruct the pursuit of sustainability outcomes $[3,11]$. Our main research objective is to use this understanding to systematically investigate the hierarchical influences of state fiscal and policy intervention on municipal commitments to energy efficiency within their internal operations. Specifically, our aim is to empirically examine how state fiscal resources, policy mandates and systems of vertical dependence affect local jurisdictions commitments to LBE sustainability endeavors.

This article advances this discussion by providing practical illustrations of LBE strategies within U.S. municipalities. Next, we explore how "contested federalism" between state and local governments can influence municipal efforts for sustainability action. We then advance our hypotheses linking state-level influences with municipal sustainability endeavors within their internal operations. We apply an analytical approach grounded in Bayesian item response theory (IRT) methodology to test these hypothesized links using data from a survey of 1124 U.S. cities. The findings connect increased state-level fiscal support for energy efficiency programs with increased municipal commitments to sustainability within their internal operations. We also find that when states implement state energy efficiency standards, municipalities are more likely to be committed to LBE activities. Our findings lead to several policy implications regarding the influences of multilevel governance systems on municipalities taking the lead in sustainability initiatives.

\section{Municipalities Taking the Lead in Sustainability}

An effective strategy for local governments to promote sustainability initiatives is to first lead by example and practice sustainability within their internal operations [6]. Across the United States, municipalities are making efforts to employ this strategy and become leaders in energy efficient sustainability. For example, the City of Austin, Texas, has committed to these efforts by establishing an office of sustainability that tracks its overall sustainability performance. Likewise, the City of Tallahassee, Florida, has formally adopted a sustainability goal that dedicates it to 100\% clean energy by 2050. Meanwhile, cities like Kyle, Texas, and Henderson, Nevada, have dedicated themselves to operating more energy efficiently by reducing their non-essential agency operations to a four-day work week. Other cities such as Burlington, Vermont, have taken great strides in sustainability to make $100 \%$ of their electric utility operations sourced from renewable energy.

Cities such as San Francisco, CA, USA; Portland, Oregon; and St. Louis, MO, USA, have implemented sustainability planning initiatives that establish and manage goals on environmentally friendly planning and smart growth strategies. Denver, Colorado, and Cambridge, Massachusetts, have both taken the lead in sustainability by dedicating themselves to using green fleets (government vehicles that rely on alternative fuels and environmentally friendly technologies). Meanwhile, cities like Seattle, Washington, and Mobile, Alabama, have taken strides to commit to carbon neutrality and energy efficiency within their public utilities and public works operations. Figure 1 shows a map of the cities highlighted in this narrative to illustrate their spatial distribution throughout the U.S. Likewise, this map supplies a visual to provide practical context behind the state and local government interactions that advance sustainability. Here, we can see that these cities are widely disbursed across the various regions of the United States.

While these cases highlight several attempts to employ government driven sustainability actions, municipalities are generally trending in these endeavors at a slow pace [12]. Yet, the locally driven nature of environmental concerns is forcing public officials to take on a heightened sense of environmental awareness. This has spawned innovation in sustainability within internal municipal operations. In 2015, the International City/County Management Association (ICMA) conducted a national poll of over 2000 U.S. local government officials on local sustainability issues [13]. This survey revealed that roughly $64 \%$ have made some type of effort to upgrade or retrofit facilities to be more compatible 
with energy efficient lighting. Other local government sustainability activities included the purchasing of fuel efficient or hybrid vehicles, retrofitting office buildings with energy efficient cooling and HVAC systems, and executing self-compliance through government building energy audits. For example, the ICMA noted that roughly $63 \%$ of the polled local governments conducted an energy audit of their own government facilities. Some localities were even reported to have upgraded their outdoor lighting systems to use energy efficient technologies that comply with Dark Sky Lighting standards.

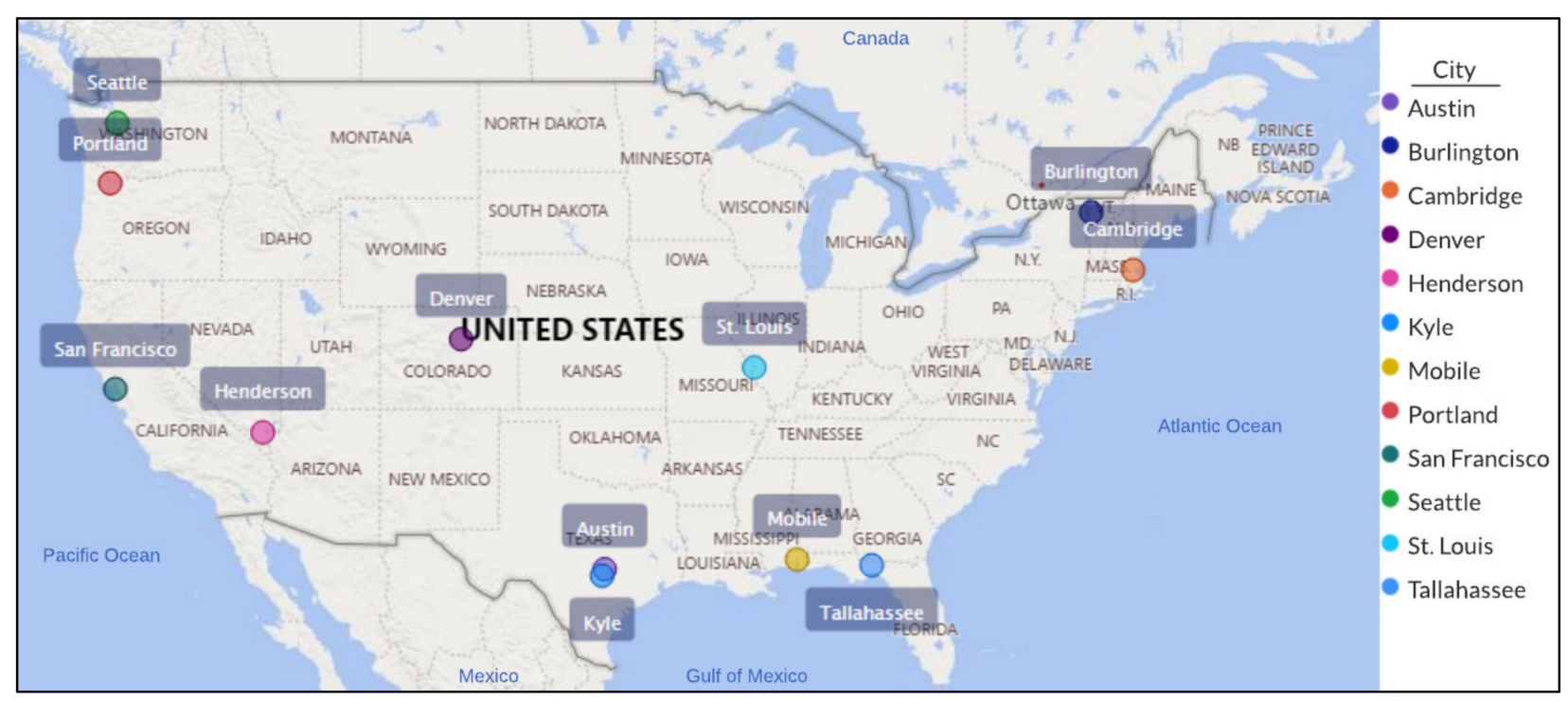

Figure 1. Map of selected cities throughout the United States implementing LBE practices.

The municipal sustainability survey data reported by Francis and Feiock [6] supports the ICMA's results and suggest that some cities are taking advanced efforts to implement sustainability in tangible ways. Their report suggests that cities often demonstrate their commitments to sustainability by making major investments in capital infrastructure. They assert that numerous jurisdictions have adopted green building programs that promote environmental performance in governmental construction and retrofitting projects. Among these cities, several apply the U.S. Green Building Council's Leadership in Energy and Environmental Design (LEED) certification to the construction and renovation of facilities [6]. This certification not only ensures that public spaces conform to green building standards, but it also sends a symbolic message publicly about the significance of sustainability.

Local governments are attempting to execute the strategy of leading by example in a variety of ways. Although some cities have taken expensive and drastic measures for sustainability, others have taken simple steps like paper reduction within business operations. Regardless of the cost and size of the effort, localities who take the lead in sustainability make a profound statement about its importance [6]. This has led communities to implement various innovations that enable them to demonstrate their commitment to this important issue. However, the question remains regarding the role of states in local government sustainability commitments. While municipalities are beginning to take the lead in sustainability, we must ponder whether states through resources and policy mandates enable or obstruct these efforts. We explore this issue further from a "contested federalism" perspective that explains how state intervention within a multilevel governance system can influence local-level policy activities.

\section{The Transaction Costs of Contested Federalism}

Rabe [1] framed the hierarchical intergovernmental relationship between state and local governments as one based upon a complicated interdependent set of relations where actors will either compete or collide around policy actions. This notion of "contested feder- 
alism" involves state and local governments coordinating or impeding policy endeavors to increase their individual and mutual benefits within a multilevel governance structure [11]. These interactions can create certain vertical dependence dilemmas as competition and policy misalignments between state and local governments can lead to distinct political transaction costs derived through commitment, agency, and administrative costs $[14,15]$.

When centralized actors force their authority upon others, this can result in externalities for the latter. This dilemma can lead to inefficiencies that result in the lack of policy execution as higher transaction costs can lead to policy inactions among local governments. States, however, can supply safeguards against these inefficiencies through incentives or constraints that reduce the chances that cities will deviate from legislative intent. In essence, states can provide a supportive structure of multilevel governance designed to provide a stable flow of exchanges. A stable and sustained flow of resources and authority can reduce uncertainty for local governments and therefore reduce commitment, agency, and administrative costs. As illustrated in Figure 2, the flow of state resources and authority is related to levels of uncertainty, which goes up as state support becomes less. In this figure, we propose that when states provide municipalities with more resources and authority, uncertainty will become lower, which will produce lower transaction costs for municipal sustainability commitments. However, uncertainty becomes elevated when states provide local governments with less resources and authority. At this point, uncertainty creates higher transaction costs for municipal sustainability actions.

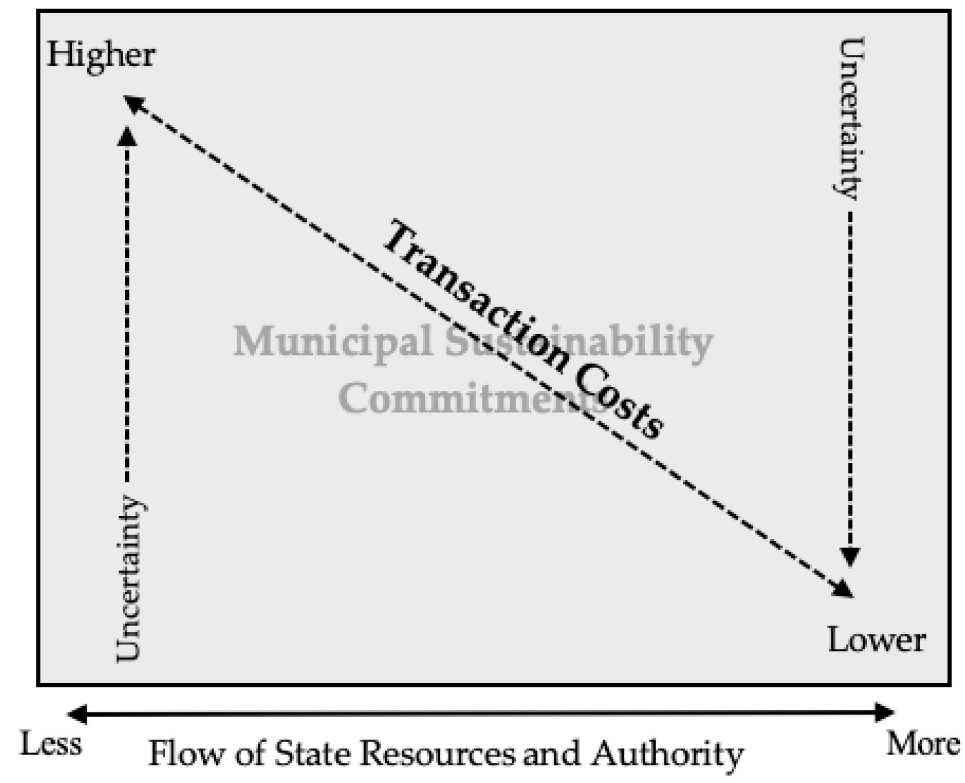

Figure 2. Transaction costs and the flow of state resources and authority.

States can reduce commitment costs with fiscal resources that ease local actors' abilities to commit to policy actions. Meanwhile, states can mitigate agency costs by providing supportive policies that rely on vertical consistency measures. Finally, the flow of authority from the states can minimize administrative costs by enabling local units to engage in administrative designs that allow them to adapt to policy uncertainties.

\subsection{Commitment Cost}

Local governments facing capacity issues will endure higher commitment costs. These costs arise when local governments face uncertainty regarding the availability of resources for policy execution. Being unsure about resource availability can make it difficult for local officials to commit to state policy mandates. Therefore, commitment cost can be lower when local governments have the resources to implement policies and higher in situations 
where they are lacking [14]. A state can therefore reduce a city's commitment costs when it provides a stable and supportive structure of resource exchanges $[14,16]$.

Resource capacity concerns can present challenges for cities in their commitment to energy reduction activities [6]. States can help cities overcome resource scarcity issues and encourage the pursuit of internal energy efficiency efforts by providing resources that promote policy outcomes. State-level fiscal support can be beneficial in assisting local units in overcoming provision difficulties by increasing local government program capacity $[17,18]$. Prior work on sustainability issues furthers this notion and demonstrates the importance of state involvement in the fiscal and programmatic capacity of localities for environmental efforts [3,7,8]. As noted by the American Council for an Energy-Efficient Economy (ACEEE) [19], states can fiscally enhance local sustainability initiatives by providing direct monetary investments or through legislative policy initiatives that incentivize energy savings. Such initiatives can be realized through ratepayer funded energy efficiency programs or system benefits charges backed by customer utility rates [19-21]. Revenue from these charges is frequently placed within a public benefits fund (PBF) to ensure continued support for energy efficiency programs [21]. Sustained support for energy efficiency at the state-level can reduce commitment costs manifested by scarcity issues at the local-level and enhance municipal capacity for sustainability efforts within internal operations. Therefore, we hypothesize the following:

Hypothesis 1. Greater financial commitment to energy efficiency within state energy program budgets will have a positive relationship with city commitments to energy efficiency programs within municipal internal operations.

\subsection{Agency Cost}

Agency costs arise when policy mandates produce goal conflict between state officials and local-level administrators [22,23]. State legislatures under political pressure to impose legislations will encounter policy misalignments when local-level officials being insulated from these pressures will execute policies based upon local needs and priorities [24]. In essence, adverse selection issues can produce information asymmetries and cause locallevel policy implementation to defect from the state's initial intent $[25,26]$. States, however, can minimize these agency defection problems when they implement vertically consistent policies that rely on citizen-driven cooperative enforcement mechanisms [27,28].

Vertically consistent policies have been hypothesized to increase agent accountability as they are theoretically reinforced with citizen participation [29]. Vertical consistency entails the alignment of state-level policies with citizen priorities and support. Vertical consistency increases local-level buy-in to policy measures by engaging citizens in collaborative efforts for policy compliance [27]. If citizens are supportive and incentivized to participate in state policy measures, local-level officials will be incentivized to comply with state directives.

As sustainability policies can have substantial local consequences, we advance that state policy standards can encourage local commitments to policies that promote vertical consistency. These policies bring the desire to maintain accountability and motivate local governments to take ownership of policy initiatives that coincide with state mandates [29]. Here, policy compliance is achieved through initiatives that encourage citizen participation. Energy policy standards directed at citizen behavior can be used as mechanisms to promote vertical consistency. Prior works support this assertion with evidence that standards such as energy efficiency minimums and residential and commercial building codes can assist local governments in encouraging citizen participation with incentivized directives for compliance [30-32].

Incentivized regulation rather than coercive rigidity can lead to more cooperative and voluntary policy enforcement [33-35]. Coercive state mandates, especially those that omit vertical consistency, can push local actors to deviate from the principal's policy goals $[36,37]$. Following this logic, we assert that states with supportive policies that align 
with local interests and encourage cost-effective energy efficiency strategies can motivate municipalities to commit to programs that rely on vertical consistency. State initiatives such as energy efficiency standards and targets that serve to encourage the public to engage in energy efficiency can prompt municipalities to embrace accountability and commit to sustainability policy solutions [31,38,39]. Therefore, we propose the following hypothesis:

Hypothesis 2. State energy efficiency standards will have a positive relationship with city commitments to energy efficiency programs within municipal internal operations.

\subsection{Administrative Cost}

Local governments can face higher administrative costs when they lack the ability to control their administrative designs or adjust to policy problems. Local government autonomy can allow local officials to make policy adjustments in the face of uncertainty to respond to policy problems more efficiently. An agency with an adaptable administrative design can produce lower transaction costs due to its ability to adjust its performance during periods of change and uncertainty [15]. Transaction costs are also lower in these instances as local autonomy precludes state interference in local agency processes. On the other hand, municipalities that are more reliant on their state systems for authority will yield higher transaction costs due to inflexibilities that can obstruct localities from easily making policy and process adjustments.

Local governments are more likely to be reliant on state flows of authority for policy implementation where state systems are more centralized [9]. The flow of authority from the states can dictate the governing activities for municipalities through formal governing relations $[40,41]$. States with higher degrees of centralization can create a strong vertical dimension of local dependence on state government for policy activities [7]. More centralization requires local governments to cooperate vertically within multilevel governance systems due to limitations in state-granted authority [20]. This means that more centralization provides less discretionary local powers to raise revenue or engage in activities that support local policy functions [40,42]. This can lead to states becoming more involved in local governing affairs, which can raise the administrative costs for local governments. With less governing autonomy, municipalities have fewer freedoms and financial resources to explore innovative ways to implement governmental functions or adjust policy responses to issue changes. Cities lacking home rule can be more susceptible to the rigidity of state regulatory mandates. More legislative oversight can impose policy directives on local governments that can hinder the pursuit of individual interests $[20,43]$. Although state policies can encourage local commitments to compliance, cities with less autonomy can be expected to have weaker abilities to explore administrative alternatives within internal operations [22,40].

Hypothesis 3. Home rule authority within states will have a positive relationship with city commitments to energy efficiency programs within municipal internal operations.

\section{Materials and Methods}

In this section, we outline our methods of analysis. In the prior section, we provided our conceptual framework, which led to three formal hypotheses that propose directional relationships between state-level interventions and municipal commitments to sustainability within their internal operations. Now we turn our attention to the analytical development that outlines our approach to testing the hypotheses. Here, we detail our data, the operations of our dependent and independent variables, as well as describe our model formulation and methodological approach. Figure 3 illustrates a synoptic scheme of our analytical approach that summarizes our methods of analysis. This figure serves as a visual map that outlines the steps of our analytical process. As shown below, our process moves from conceptualization to analytical development, and finally to model formulation and analysis. 


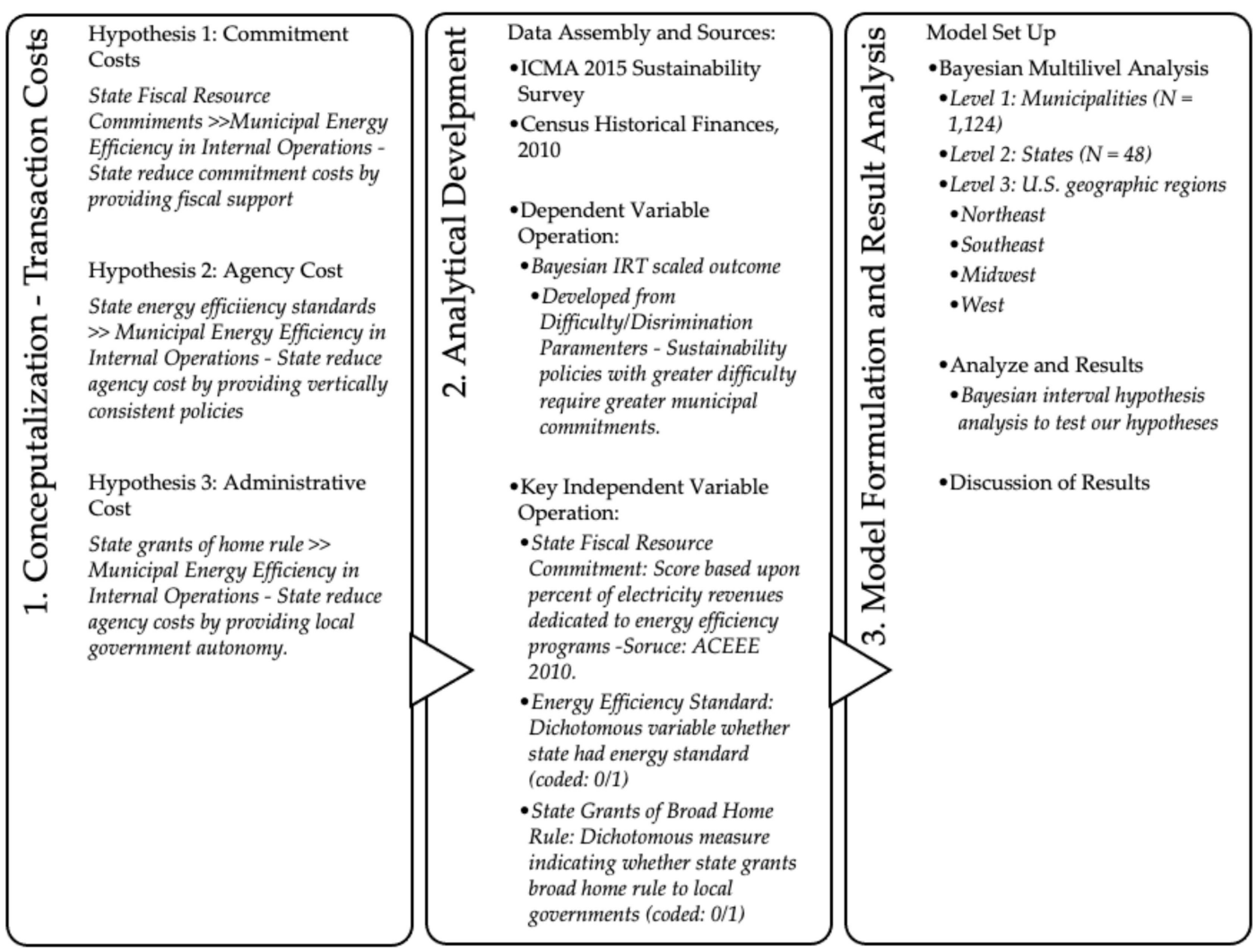

Figure 3. Synoptic scheme of analytical approach to estimating municipal internal energy efficiency programs.

\subsection{Data}

The presented hypotheses are tested by examining the effects of state fiscal and policy intervention on municipal commitments to energy sustainability within their internal government operations. The data for the dependent variable come from 15 dichotomous indicators on energy sustainability found within the International City/County Management Association's (ICMA) Local Government Sustainability Practices, 2015 survey. The survey was originally sent to 8562 U.S. city and county governments. This survey yielded a response rate of $22 \%$, with 1899 local government responding. We limited our analysis only to cities from the survey sample that reported financial data within the U.S. Census Historical Finances for Individual Governments for 2010 (Census Bureau 2012). This reduced the sample for our analysis to 1124 cities across 48 states. ICMA surveys generally have greater response rates from cities with larger populations and that have the council-manager form of government. Therefore, caution should be used while approaching the findings from this analysis due to the possibility of generalizability issues resulting from sample biases within the data.

\subsection{Dependent Variable}

The dependent variable measures the levels of commitment made by municipalities to energy efficiency tools for internal functions within the last five survey years (2011-2015). The ICMA survey asked local government officials a series of 15 questions about whether their cities implemented various sustainability programs within the five-year period. This resulted in 15 individual dichotomous variables that indicated 1 if the city implemented a given program, and 0 otherwise. We created our dependent variable by calculating the standardized Bayesian means from the item response theory (IRT) estimates of these items. This resulted in a scaled outcome variable based upon the predicted latent response traits across the individual survey items. Here, we assign a weighting scheme to items, controlling for the fact that some policies are cheaper and more frequently implemented 
than others [44]. The analysis uses the difficulty and discrimination parameter estimates for the assessed policy tools to predict a city's commitment to energy sustainability [44]. We use this approach to quantify latent traits to empirically capture a municipality's commitment to various internal energy policy programs and assess the probability of relationships. Within this approach, policy tools with higher degrees of difficulty require greater commitments for implementation. Table 1 highlights the estimated latent traits of the internal energy efficiency programs used for our dependent variable. This table reports the difficulty and discrimination parameters, along with the proportion of cities implementing these programs. The programs within this table are listed in descending order based upon their estimated difficulty parameter.

Table 1. Energy efficiency programs for municipal internal operations.

\begin{tabular}{|c|c|c|c|}
\hline Energy Program & Difficulty & Discrimination & Proportion \\
\hline Installed geo-thermal systems in govt. facilities & $2.732 * * *$ & $1.081^{* * *}$ & 0.204 \\
\hline $\begin{array}{l}\text { Generated electricity through refuse, disposal, wastewater } \\
\text { treatment or landfill operations }\end{array}$ & $2.642^{* * *}$ & $1.126^{* * *}$ & 0.075 \\
\hline $\begin{array}{l}\text { Required all govt. renovations to be certified green (LEED, } \\
\text { Energy Star, etc.) }\end{array}$ & $1.894^{* * *}$ & $2.246^{* * *}$ & 0.106 \\
\hline Established fuel efficient target for government fleet & $1.689^{* * *}$ & $1.385^{* *}$ & 0.19 \\
\hline Established policy to only purchase Energy Star equipment & $1.593^{* * *}$ & $1.338^{* * *}$ & 0.669 \\
\hline $\begin{array}{l}\text { Required all new govt. construction to be certified green (LEED, } \\
\text { Energy Star, etc.) }\end{array}$ & $1.521 * * *$ & $2.445^{* * *}$ & 0.076 \\
\hline Installed solar panels & $1.286^{* * *}$ & $1.421^{* * *}$ & 0.354 \\
\hline Installed charging stations for electric vehicles & $1.189^{* * *}$ & $1.421^{* * *}$ & 0.319 \\
\hline Increased purchase of hybrid, electric and fuel-efficient cars & $0.654^{* * *}$ & $1.766^{* * *}$ & 0.144 \\
\hline $\begin{array}{l}\text { Upgraded/retrofitted to energy efficiency water and sewer } \\
\text { pump systems }\end{array}$ & $0.602 * * *$ & $1.342^{* * *}$ & 0.497 \\
\hline Upgraded/retrofitted traffic signals to energy efficient lighting & $0.132 * *$ & $1.398^{* * *}$ & 0.675 \\
\hline Upgraded/retrofitted govt. facilities to energy efficient heating & 0.019 & $1.858^{* * *}$ & 0.585 \\
\hline $\begin{array}{l}\text { Upgraded/retrofitted street and exterior lighting for } \\
\text { energy efficiency }\end{array}$ & $-0.304^{* * *}$ & $1.586^{* * *}$ & 0.467 \\
\hline Upgraded/retrofitted govt. facilities to energy efficient lighting & $-0.544^{* * *}$ & $2.377^{* * *}$ & 0.162 \\
\hline Conducted energy audits & $-0.571^{* * *}$ & $1.925^{* * *}$ & 0.222 \\
\hline
\end{tabular}

$$
{ }^{* *} p<0.05 ;{ }^{* * *} p<0.01 \text {. }
$$

\subsection{Model Development}

We assess the IRT measure using a multilevel effects hierarchical linear modeling approach that incorporates Bayesian analyses to assess a data structure that crosses municipal jurisdictions, state geographic boundaries and U.S. geographic regions. As this analysis analyzes latent decision traits for sustainability programs, the Bayesian approach allows us to evaluate unknown parameters based upon prior knowledge. Theoretically, prior information and experiences can lead public managers to constantly evolve in their decisions and strategies around sustainability initiatives [45]. This model allows for simulated probabilities regarding the estimated outcomes around actors' decisions. In general, Bayesian models use probability statements that employ Markov chain Monte Carlo (MCMC) sampling algorithms to assess the posterior distribution. These sampling algorithms allow evidence within the data to be informed by prior information to empirically approximate predictions. Here, the Bayesian approach allows us to generate predictions based upon the difficulty and discrimination parameters of the indexed outcome variable.

\subsection{Commitment Cost Measure: State Fiscal Support}

In 2010, the ACEEE reported how states faired regarding efforts to promote energy efficiency using 2009 fiscal year data. Among other metrics, this report assessed electricity program budgets in 2010 for state sponsored programs designed to promote energy efficiency. This metric consists of funding dedicated towards ratepayer programs financed through charges within customer utility bills and collected within a state administered 
PBF. The ACEEE scored states on a scale of 0 to 5 based on the levels of energy efficiency budgets within states as a percent of utility revenues. Budgets that were at least $2.5 \%$ of revenues were given a score of 5 . For every $0.25 \%$ less, the ACEEE decreased a state's score by 0.5 points. For the current analysis, state energy funding is represented by the score assigned to a state by the ACEEE. Higher scores represent greater financial commitment by a state to energy efficiency programs. States with less financial commitment to energy programs are deemed as imposing higher commitment costs on local governments. Table 2 outlines the scoring scheme based on the percentages of state budgets dedicated towards energy efficiency programs. This information derived from The 2010 State Energy Efficiency Scorecard, published by the ACEEE [19].

Table 2. ACEEE score of state energy efficiency program budgets.

\begin{tabular}{cc}
\hline Percent of Revenues & Score \\
\hline $2.50 \%$ or greater & 5 \\
$2.25-2.49$ & 4.5 \\
$2.00-2.24$ & 4 \\
$1.75-1.99$ & 3.5 \\
$1.50-1.74$ & 3 \\
$1.25-1.49$ & 2.5 \\
$1.00-1.24$ & 2 \\
$0.75-0.99$ & 1.5 \\
$0.50-0.74$ & 1 \\
$0.25-0.49$ & 0.5 \\
Less than 0.25 & 0 \\
\hline
\end{tabular}

Reprinted with permission from Ref. [19]

\subsection{Agency Cost Measure: Policy Standards}

We use energy efficiency standards to gauge the significance of state directives for energy sustainability. Such policies set a minimum amount of energy savings and allow utilities to choose how to best achieve those savings. These energy efficiency standards, while often aimed at utility providers, generally include consumer focused options such as demand-side management incentives, peak demand reductions, building codes, and consumer-directed energy efficiency programs [46]. The analysis uses 2010 data drawn from the Pew Center on Global Climate Change to assess whether states established an energy efficiency standard for utility providers or programs. The existence of such standards represents state policy standards that promote energy efficiency and is denoted by the variable state energy efficiency standards. This variable is captured with a dichotomous measure with 1 representing that a state had an energy efficiency standard and 0 otherwise. Because there is a wide variety in the ways states implement energy standards [47], this analysis measures the existence of policy standards as opposed to the type or degree to which they are implemented. We see states with enacted energy efficiency standards as having vertically consistent policies that lend towards lower agency costs.

\subsection{Administrative Cost Measure: Vertical Dependence}

We use the grant of home rule authority within a state to gauge administrative costs and capture the ability of local governments to obtain broad home rule. The level of governing authority provided to local governments has implications on their abilities to adopt and execute policies. This can especially be true when it comes to limitations in local authority for energy regulation [20]. Therefore, the variable broad home rule granted within a state is used to measure whether a state grants its local governments broad local governing powers. States lacking broad home rule are considered as having stronger systems of vertical dependence and therefore have higher administrative costs. Meanwhile, states granting home rule represent those with weaker systems. We captured this variable with a dichotomous measure represented by 1 for a state affording local governments 
broad home rule, and 0 otherwise. Data for this factor come from the National Associations of Counties [48], as well as the authors' assessment of individual state laws that govern home rule.

\subsection{Controls}

All models include variables that control for local government institutional arrangements, local government spending capacity, local demands, demographic and economic characteristics. A city's institutional arrangements is denoted by a dummy variable capturing whether it operates under the council-manager form of government $(0=$ no; $1=$ yes $)$. The data for this variable come from the ICMA 2015 sustainability survey. Local government spending capacity is measured by per capita local tax revenue from municipal sales and property taxes, while the logged population and population density capture local government population size and the ratio of the population relative to a government's land area. The data for per capita taxes come from the U.S. Census 2010 historical finances data, while the population and population density data come from the 2010 U.S. Census national survey. We capture a city's community and political attributes with racial, age and socio-economic demographic variables that are set to reflect a community's political and environmental needs for sustainability $[4,8,12,49]$. Racial demographics are measured by the percent of the population white non-Hispanic, while age is measured by the percent of a population considered to be "young adults" between the ages of 25 and 44 . City socio-economic attributes are measured by the GINI coefficient of income inequality and by a city's median property values. All demographic and socioeconomic data come from the 2010 U.S. Census. Finally, the models include sets of dummy variables that capture variance across states and U.S. geographic regions. The data for our geographic dummy variables come from the Census 2010 historical finances data. We report the descriptive statistics for all variables in Table 3.

Table 3. Descriptions of the modeled variables.

\begin{tabular}{|c|c|c|c|c|c|}
\hline & Mean & Proportion & Stand. Deviation & Min & $\operatorname{Max}$ \\
\hline $\begin{array}{c}\text { Dependent Variable } \\
\text { Internal energy sustainability IRT } \\
\text { Independent Variables }\end{array}$ & $3.97 \times 10^{-9}$ & - & 0.999 & -1.69 & 3.05 \\
\hline State energy funding commitment & 1.76 & - & 1.707 & 0 & 5 \\
\hline State energy efficiency standards & - & 0.58 & 0.493 & 0 & 1 \\
\hline Broad home rule granted within state & - & 0.638 & 0.481 & 0 & 1 \\
\hline Council-manager & - & 0.674 & 0.468 & 0 & 1 \\
\hline Per capita taxes & 622.78 & - & 536.11 & 0 & 5620 \\
\hline Population (logged) & 9.72 & - & 1.25 & 7.75 & 15.15 \\
\hline Population density & 2381.18 & - & 1990.08 & 99.49 & $16,443.27$ \\
\hline White non-Hispanic & 0.798 & - & 0.171 & 0.057 & 1 \\
\hline Young adults & 0.263 & - & 0.052 & 0.031 & 0.482 \\
\hline GINI & 0.424 & - & 0.056 & 0.266 & 0.606 \\
\hline Median property values & $256,470.80$ & - & $493,532.40$ & 4050 & $9,741,000$ \\
\hline \multirow[t]{2}{*}{ Group Variables } & \multicolumn{5}{|c|}{ Observations per group } \\
\hline & No. of groups & Min. per group & $\begin{array}{l}\text { Average per } \\
\text { group }\end{array}$ & $\begin{array}{l}\text { Max per } \\
\text { group }\end{array}$ & \\
\hline Geographic region & 4 & 99 & 281 & 377 & \\
\hline State & 48 & 1 & 23.4 & 112 & \\
\hline
\end{tabular}

Note: $\mathrm{N}=1124$.

\section{Results}

Estimates from the Bayesian regression model are reported in Table 4. This output reveals estimated effects on the IRT predicted traits for energy sustainability commitments within internal municipal operations. This table reports the posterior means of the parameter distributions, the Monte Carlo standard errors, and the credible intervals for parameter 
estimates with a 95\% probability. Post-estimation interval hypothesis tests were generated based upon the Bayesian model parameters to validate the acceptance of the hypotheses.

Table 4. Bayesian multilevel regression for internal energy efficiency programs.

\begin{tabular}{|c|c|c|c|c|}
\hline & Mean & $\begin{array}{l}\text { Monte Carlo } \\
\text { Stand. Error }\end{array}$ & \multicolumn{2}{|c|}{ Equal Tailed $95 \%$ Credible Interva } \\
\hline \multicolumn{5}{|l|}{ Key Independent Variables } \\
\hline State electricity program funding & 0.041 & 0.007 & -0.023 & 0.103 \\
\hline State energy efficiency standards & 0.154 & 0.0015 & -0.016 & 0.332 \\
\hline $\begin{array}{l}\text { Broad home rule granted within state } \\
\text { Controls }\end{array}$ & 0.092 & 0.001 & -0.079 & 0.257 \\
\hline Council-manager & 0.163 & $3.50 \times 10^{-4}$ & 0.051 & 0.276 \\
\hline Per capita tax revenue & $2.41 \times 10^{-4}$ & $3.00 \times 10^{-7}$ & $1.41 \times 10_{-}^{-4}$ & $3.39 \times 10^{-4}$ \\
\hline Population (logged) & 0.347 & $1.21 \times 10^{-4}$ & 0.301 & 0.394 \\
\hline Population density & $9.50 \times 10^{-6}$ & $1.10 \times 10^{-7}$ & $-2.11 \times 10^{-5}$ & $4.01 \times 10^{-5}$ \\
\hline White non-Hispanic & 0.425 & 0.0014 & -0.068 & 0.783 \\
\hline Young adults & 1.171 & 0.003 & 0.011 & 2.324 \\
\hline GINI coefficient & 2.11 & 0.0029 & 1.036 & 3.182 \\
\hline Median property values & $4.49 \times 10^{-8}$ & $2.40 \times 10^{-10}$ & $-5.54 \times 10^{-8}$ & $1.45 \times 10^{-7}$ \\
\hline Intercept & -5.41 & 0.013 & -6.24 & -4.54 \\
\hline \multicolumn{5}{|l|}{ Variance Between Groups } \\
\hline Geographic Region & 0.076 & 0.013 & 0.004 & 0.444 \\
\hline State & 0.025 & 0.0005 & 0.005 & 0.062 \\
\hline Error term & 0.663 & $1.57 \times 10^{-4}$ & 0.609 & 0.721 \\
\hline MCMC iterations & 70,000 & & & \\
\hline Burn-in & 12,500 & & & \\
\hline MCMC sample size & 57,500 & & & \\
\hline N observations-Level 1 & 1124 & & & \\
\hline N States-Level 2 & 48 & & & \\
\hline N Geographic Regions_Level 3 & 4 & & & \\
\hline
\end{tabular}

Preliminary models revealed signs of high autocorrelation, which led to the use of 70,000 iterations less 12,500 burn-ins yielding an MCMC sample size of 57,500. This sample size produced a chain sufficient to generate stable estimates within the posterior distribution with acceptable credible intervals [50]. Figures 4-6 illustrate post-estimation diagnostics that provide trace-plots, histograms, autocorrelation plots, and density plots for each of the three key independent variables. Figure 4 shows diagnostic figures for the state electricity program budget variable, while Figure 5 provides illustrative diagnostics for state energy efficiency standards. Meanwhile, Figure 6 shows post-estimation diagnostics for the variable that denotes broad home rule granted within a state. The trace-plots within each figure plot the simulated parameter values against their respective iterations. As shown in the figures below, the parameters for all three variables fully converged as suggested by the dense vertical lines of the trace-plots. This means that the MCMC simulations completed their convergence, thus allowing the model to draw valid samples from the desired posterior distribution. The histograms in Figures 4-6 show that the data are normally distributed and therefore confirm that the simulations of the respective marginal posterior distributions are good for all three variables. The autocorrelation plots in these figures also indicate good convergence as the autocorrelations become negligible after about 30 lags. The Kernel density plots within the three figures likewise show signs of good model convergence. These density plots show that the first and second halves of the MCMC samples are identical to the overall samples taken for all three of the key independent variables. 


\section{State Electricity Program Budget}
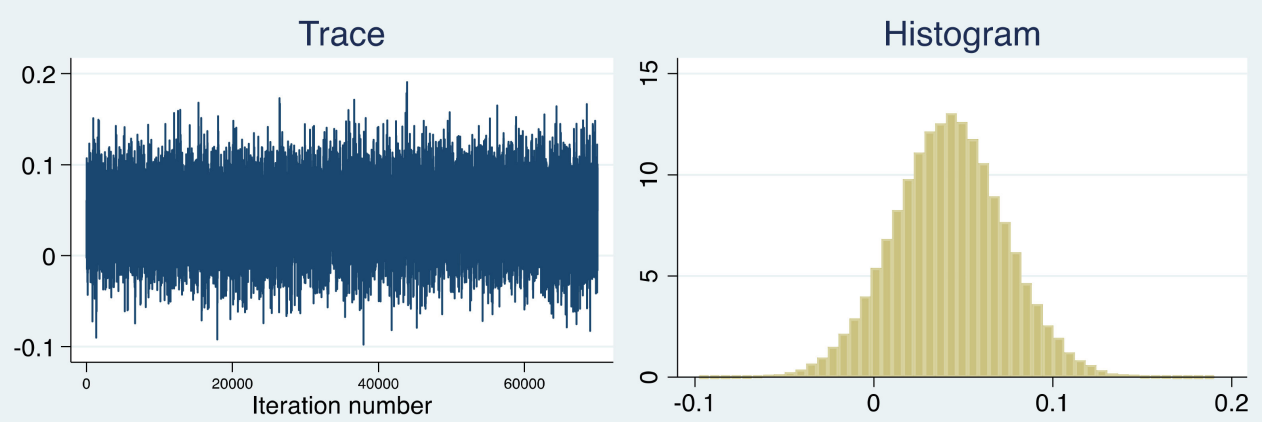

Autocorrelation
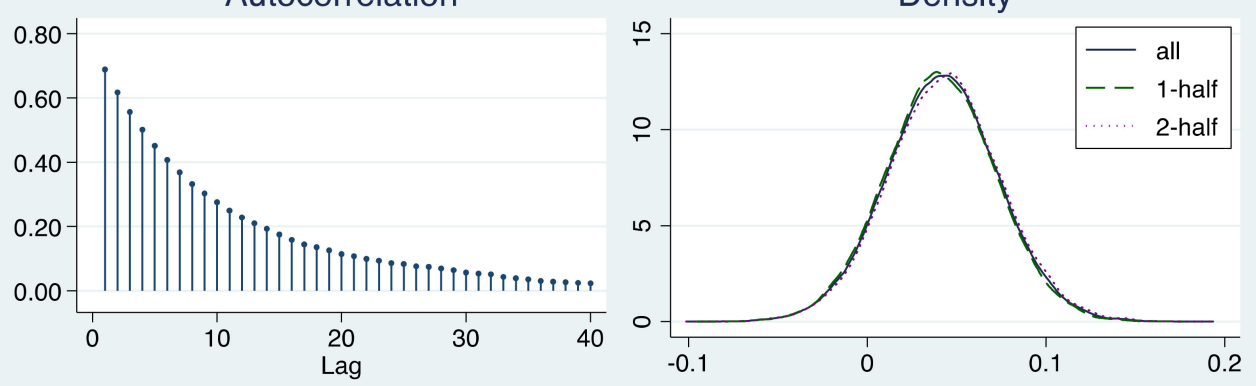

Figure 4. Convergence diagnostics for state electricity program budgets.

\section{State Energy Efficiency Standards}

Trace

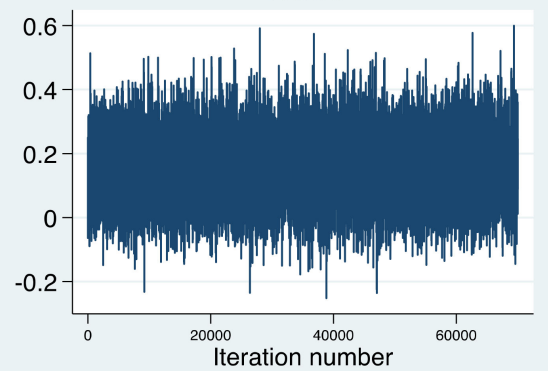

Autocorrelation

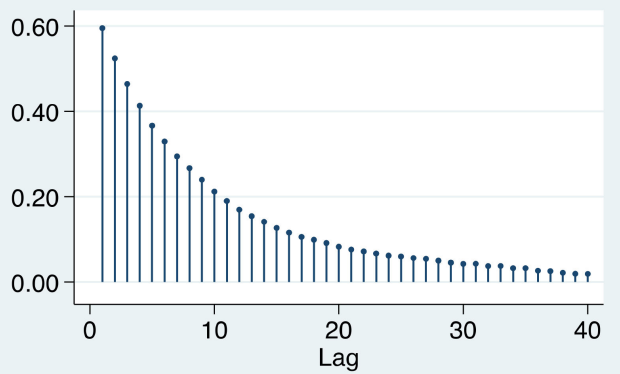

Histogram

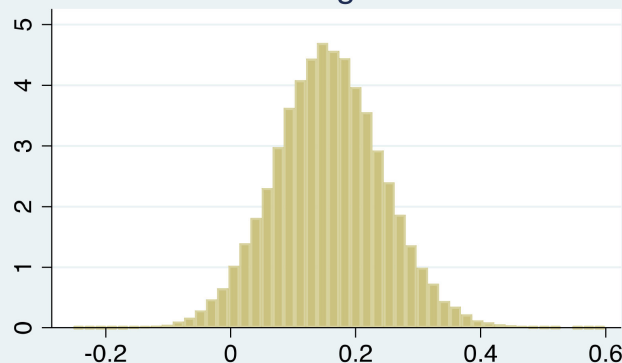

Density

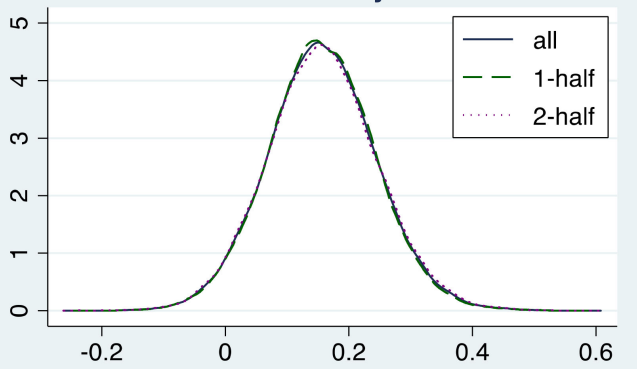

Figure 5. Convergence diagnostics for state energy efficiency standards. 


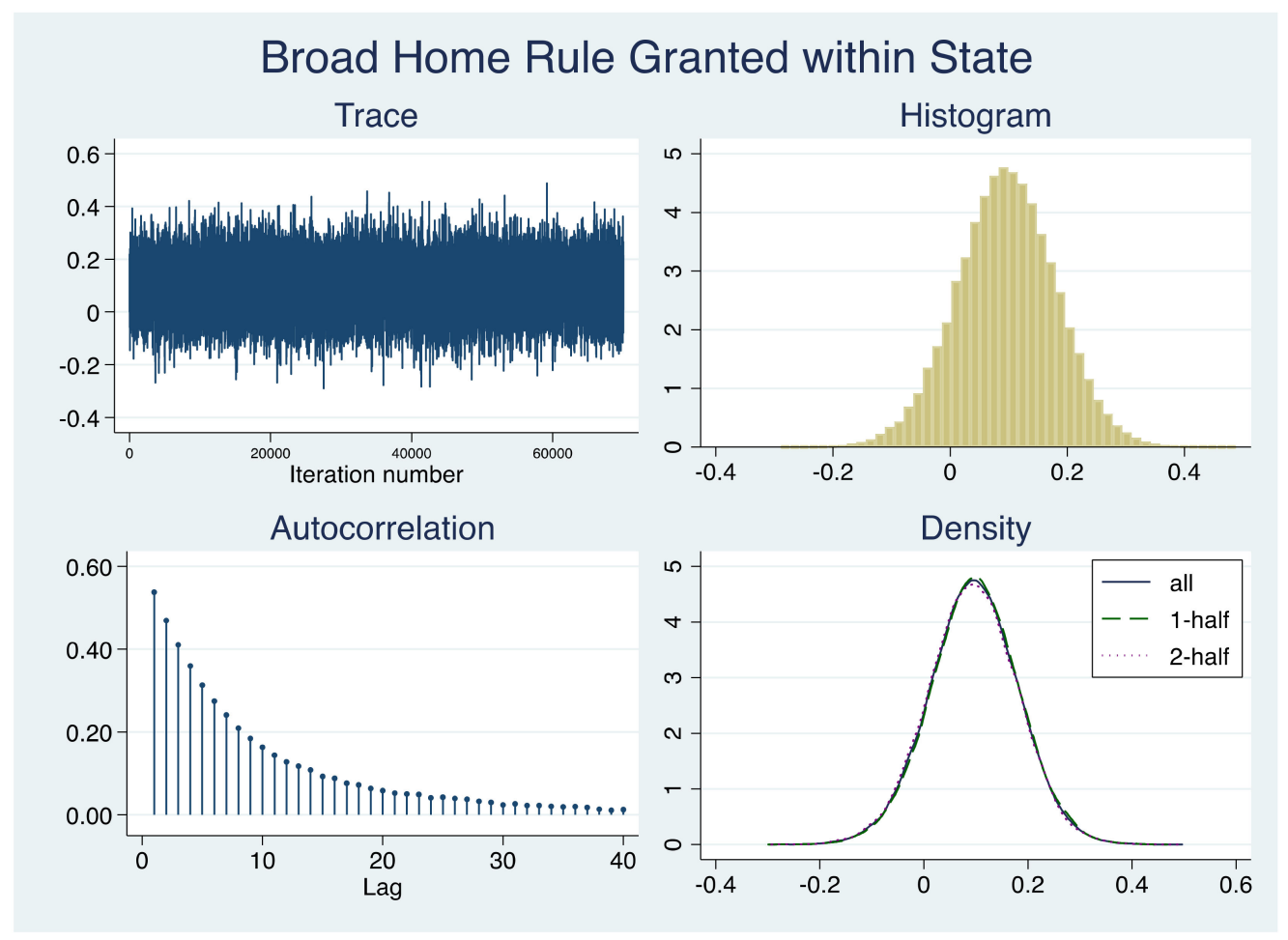

Figure 6. Convergence diagnostics for broad home rule granted within state.

Bayesian analyses produce clear probability statements about the likelihood of relational events. This allows analysts to assess outcomes by expressing the percent chance that an event is likely to occur. Standard regression analyses rely on interpretations based upon ambiguous coefficients meeting a statistical requirement. With Bayesian statistics, analysts can make practical decisions regarding the sufficiency of evidence to establish relationships. For the current analysis, a conservative determination of statistical sufficiency will maintain a $10 \%$ chance of the parameter resting outside the credible interval range. We interpret the estimation results of Table 4 using the interval hypothesis tests reported in Table 5 . The interval hypothesis tests for these analyses display the probability that the reported parameter means for the key factors are above 0 .

Table 5. Bayesian interval hypothesis tests (greater than 0).

\begin{tabular}{ccc}
\hline Municipal Internal Energy Efficiency Programs & Mean & Monte Carlo Standard Error \\
\hline State energy funding commitment $(p>0)$ & 0.905 & 0.004 \\
State energy efficiency standards $(p>0)$ & 0.961 & 0.002 \\
Broad home rule $(p>0)$ & 0.864 & 0.004 \\
\hline
\end{tabular}

The results in Table 4 suggest the existence of a positive relationship between state energy funding commitments and item response traits for municipal commitments to energy sustainability within internal operations. Per Table 5 , the related post-estimation output reveals a $90.5 \%$ chance that greater state level fiscal commitments to energy programs positively affect municipal commitments to energy efficiency within internal functions. This statistic lends support for Hypothesis 1 in that there is less than a 10\% chance of the model parameter falling outside the credible interval. Consistent with previous studies, the current model suggests that fiscal support within multilevel governance environments $[2,7,8]$ plays a substantial role in local government sustainability endeavors. Municipalities that reside within states with greater portions of their budgets dedicated to energy funding, had a higher probability of being committed to functioning in a more energy efficient manner. 
Table 4 also reveals a positive relationship between state policy standards for energy efficiency minimums and municipal commitments to internal energy sustainability. The related interval hypothesis test in Table 5 reveals a $96.1 \%$ probability statistic for this relationship. This means that there is roughly a $96 \%$ chance that state energy efficiency standards encourage municipal commitments to sustainability within internal operations. This lends evidence in support of Hypothesis 2 in that the establishment of state standards for energy efficiency promotes municipal commitments to energy efficiency within internal governmental functions. Consistent with prior work, this suggests that states that provide policy support through vertical consistency measures can lower agency costs and stimulate policy compliance among local jurisdictions $[3,27]$.

The result in Table 4 shows a positive relationship between broad home rule granted within states and sustainability commitments within municipal operations. Surprisingly, the interval hypothesis test in Table 5 reveals only an $86.4 \%$ probability for Hypothesis 3 . Because there is greater than a $14 \%$ chance that the finding falls outside the credible interval range, we assume the evidence to be too insufficient to retain our hypothesis. Although the probability of this relationship appears to be high, we use caution in our interpretations with a conservative estimation of the results.

\section{Discussion}

This study extends the literature on sustainability actions within multilevel governance systems by examining the roles of state intervention in municipal decisions to commit to sustainability within their internal operations. This essay proposes that multilevel governance exchanges can greatly affect municipal decisions to operate more energy efficiently. Specifically, the transaction costs of contested federalism impact city endeavors to become more energy efficient within their internal operations. States can either guide or obstruct local sustainability efforts with the transaction costs of their governance systems. The current research explored this proposition by employing IRT methodology to examine the effects of state-level constraints on municipal commitments to energy efficient sustainability within agency operations. The findings behind the current research bring major implications for consideration regarding municipal decisions to operate more sustainably within the face of state and local relations.

\subsection{Municipal Sustainability Commitments and State-Level Support}

The results revealed an important connection between state fiscal and policy interventions and local sustainability innovations. Increased state funding for energy efficiency leads to greater municipal commitments to energy savings within internal operations. Meanwhile, our findings make a connection between vertically consistent policy measures and enhanced local commitments to state priorities. The IRT analysis assists in validating these findings by allowing us to examine the difficulty trait for municipal energy program implementation.

The empirical results suggest that commitment costs will be lower for cities in their sustainability efforts when states dedicate more resources toward energy funding. Likewise, state-level policy mandates can reduce the agency costs of policy implementation. The key point is that when states support policy implementation, cities will more easily commit to policy outcomes. This finding aligns with the work of Feiock and West [51] and reveals a strong connection between state-level involvement and local government sustainability activities. Within the context of the current analysis, commitments to energy sustainability within internal operations are closely connected to policy support from the state-level. From a theoretical standpoint, this relationship can be related to states supplying supportive multilevel governance environments and thus lowering the transactions of "contested federalism". Our work lends support to the findings of Homsy and Warner [2] and makes an empirical connection between multilevel governance support and enhanced municipal government sustainability actions. The capacity of municipalities to commit to sustainability is affected by the external environment in which they function. Consistent 
with the works of Hawkins [7] and Hamilton et al. [40], our results suggest that supportive external environments can reduce commitment and agency costs and spark cities to become more committed to innovations in organizational operations.

\subsection{State-Level Support and Local Government Capacity}

From a practical standpoint, our findings suggest that if state governments support sustainability initiatives, local governments will have the capacity to enhance their efforts for such programs. The current findings are consistent with the work of Wang et al. [52] and suggest that the enhancement of organizational resources, whether fiscal, human, or technical, can help organizations do more for sustainability with less. Municipalities are often faced with resource limitations that present challenges in the development and implementation of programs. While local officials desire to operate agencies more sustainably, limited resources can preclude them from executing their desires in a feasible manner [6]. Situations where states provide resources that enhance fiscal or technical capacity allow localities to make investments in infrastructure and business enhancements that provide improved and energy efficient productivity.

Where the benefits of fiscal resources are obvious, human, and knowledge-based capital can bring benefits by enhancing local organizational expertise. Such value can be realized by increasing the technical capacity in city staff for the execution of innovative sustainability efforts. At face value, cities can take approaches to sustainability using low-cost efforts to reduce energy consumption. Yet, they may lack the expertise that can allow them to implement more advanced approaches that can maximize benefits. State investments in energy conservation can allow cities to overcome this dilemma through vertical cooperation mechanisms such as information sharing and policy coordination. As an example, Fowler [20] notes how intergovernmental agreements for climate change or green buildings can advance the adoption of certain technologies. Although this example emphasizes interstate relations, similar agreements between the state and local levels can still lend to fiscally constrained communities gaining the technical competence to collect and analyze data that can inform the use and performance of appropriate technologies.

\subsection{Central Government Influences on Local Actors}

The findings also point to broader issues regarding central government influences on fragmented local actors. A growing body of work within the government sustainability literature highlights how centralized governments affect the sustainability choices of their local governmental units. The current findings lend to this research vein with empirical evidence that suggests positive relationships between state government influences and local government sustainability initiatives. While our work emphasized this issue within a U.S. context, its findings align with other works that highlight this issue from an international perspective. For example, Nesticò and De Mare [53] found centralized support from Italy's national government to be influential in local government initiatives for sustainable revitalization. Likewise, our results are in support of the findings of Sun et al. [54] who found central government assistance to be key for influencing Chinese local governments to engage in efforts of environmental supervision. Furthermore, they found the costs of environmental initiatives to be related to the levels of action taken by the central and local governments. Thus, their work made an empirical link between low-cost scenarios and more sustainability actions taken by the central and local governments, which aligns with our transaction cost assumptions.

Given these assumptions, the current results suggest that a lack of central government support increases costs for local governments, making it difficult for them to integrate sustainability actions into their internal operations. Akrofi and Akanbang [55] produced similar findings when they found local government sustainability involvement in Ghana to be limited when the central government provided less guidelines and technical support for energy planning. The lack of multilevel governance support increases transaction costs and diminishes local government sustainability commitments. Our findings suggest that state 
government resources can reduce local government transaction costs, therefore enabling municipalities to strengthen their commitments to sustainability actions.

\section{Conclusions}

This article makes a key contribution to the literature that explores local government approaches to sustainability issues. This work takes a unique approach to fill a literary gap by exploring the role of state and local relations in local government efforts to promote energy efficiency. Specifically, this work looks at local governments and their efforts to act as leaders in sustainability by improving energy efficiency within their internal operations. The overarching lesson gleaned from this analysis is that state government resources and policies play a significant role in shaping local governments' commitments to sustainability. While the current work does not explicitly examine intergovernmental cooperation, it does suggest that such interactions encourage local governments to enrich their sustainability practices. This lends to the broader implication that state government resources provide local governments support to lead in sustainability. Such support can allow local governments to promote sustainability by demonstrating their commitment and sending the message publicly that sustainability is a vital issue. This gives the impression that sustainability issues are important enough for localities to lead by example and invest limited resources and capital in policies that promote renewable and clean energy within internal governmental practices.

Leading by example makes a clear statement to stakeholders by actively expressing environmental stewardship and demonstrating responsible public management [6]. If governments are willing to operate in a more energy efficient manner, stakeholders will likely reciprocate these efforts with increased buy-in. Likewise, commitments to energy efficiency exemplifies managerial and fiscal responsibility [6] and expresses to the community government accountability. The current findings further this notion by demonstrating that cities take the lead in sustainability initiatives when states promote sustainability through increased multilevel governance support. Along these lines, we can conclude that increased state support leads to increased city commitments to sustainability, which can therefore lead to community stakeholder buy-in.

Local governments are engaging in sustainability in a tentative fashion [12], however, intergovernmental cooperation is allowing them to play an increasingly important role [20]. With the assistance of state resources, cities can commit to addressing energy efficiency and sustainability in a manner that benefits the overall local community. This advances the importance of understanding how sustainability can be promoted at multiple levels of government $[6,20]$. Future research should expand this point and examine the influences of state resources on collaborative local government endeavors. From here we can look to expand the literature by assessing the empirical and theoretical linkages between multilevel governance support structures and the self-organization of fragmented local units in pursuit of sustainability outcomes. The current analysis shed some light on this issue by highlighting the connection between state interventions and sustainability within local operations. However, it merely scratched the surface of the importance of the intergovernmental connection between cities and states for sustainability.

Future work should also include an examination of the effects of economic policy on municipal sustainability choices. Prior research suggests that the economic environment matters [56]. Therefore, scholarship is beginning to take a keen interest in the relationship between energy consumption and economic growth. As Alkhars et al. [57] point out, interests in the connection between local sustainability endeavors and economic growth are burgeoning within the sustainability literature. Therefore, it is vital to assess how economic policies influence municipal sustainability actions. It is important for future analyses to consider this question from the perspective of multilevel governance as state policies can have a major influence on local economic endeavors [36]. The current analysis leaves room for future work to explore local government energy sustainability, while also considering the importance of state and local policies for economic growth. An in-depth integration of 
state and local relations with a special emphasis on economic impacts can bring a more robust understanding of the issues surrounding local governments as they look to advance sustainable energy endeavors.

Finally, our use of ICMA survey data lends to possible biases regarding institutional arrangements and city populations sizes. Most responses for this analysis came from larger jurisdictions with the council-manager form of government. Additionally, this study's data were drawn from municipalities that self-reported their own sustainability initiatives. Municipal sustainability actions are taken in tentative and uneven approaches [12]. Therefore, we must use caution when drawing conclusions, as cities generally have low levels of policy adoption for sustainability endeavors [3]. Nevertheless, the lack of sustainability research that studies the latent traits behind local policy adoption within a multilevel governance context adds to this study's contribution. Our evidence underscores the importance of state-level policy actions in municipal LBE endeavors. A framework based upon a stable system of state and local government exchanges can mitigate the transaction costs of "contested federalism" as cities look to lead by example and advance sustainability outcomes within their daily government operations.

Author Contributions: Conceptualization, J.L.F. and A.J.R.L.; methodology, J.L.F.; software, J.L.F.; validation, J.L.F. and A.J.R.L.; formal analysis, J.L.F. and A.J.R.L.; investigation, J.L.F.; resources, J.L.F.; data curation, A.J.R.L.; writing-original draft preparation, J.L.F.; writing-review and editing, A.J.R.L.; visualization, J.L.F.; supervision, J.L.F.; project administration, J.L.F. Both authors have read and agreed to the published version of the manuscript.

Funding: This research received no external funding.

Institutional Review Board Statement: Not applicable.

Informed Consent Statement: Not applicable.

Data Availability Statement: Data for this project can be found at https: / icma.org/documents / icma-survey-research-2015-local-government-sustainability-practices-survey-report (accessed on 30 May 2021).

Conflicts of Interest: The authors declare no conflict of interest.

\section{References}

1. Rabe, B. Contested federalism and American climate policy. Publius J. Fed. 2011, 41, 494-521. [CrossRef]

2. Homsy, G.C.; Warner, M.E. Cities and sustainability: Polycentric action and multilevel governance. Urban Aff. Rev. 2015, 51, 46-73. [CrossRef]

3. Farmer, J.L. State-Level Influences on Community-Level Municipal Sustainable Energy Policies. Urban Aff. Rev. 2021, 1078087421995262. [CrossRef]

4. Krause, R.M. Policy innovation, intergovernmental relations, and the adoption of climate protection initiatives by US cities. J. Urban Aff. 2011, 33, 45-60. [CrossRef]

5. ACEEE. To Advance Efficiency, State Governments Go Local; American Council for an Energy-Efficient Economy (ACEEE): Washington, DC, USA, 2011.

6. Francis, N.; Feiock, R.C. A Guide for Local Government Executives on Energy Efficiency and Sustainability. Available online: http: //www.businessofgovernment.org/report/guide-local-government-executives-energy-efficiency-and-sustainability (accessed on 16 October 2019).

7. Hawkins, C.V. Smart growth policy choice: A resource dependency and local governance explanation. Policy Stud. J. 2011, 39, 679-707. [CrossRef]

8. Saha, D. Factors influencing local government sustainability efforts. State Local Gov. Rev. 2009, 41, 39-48. [CrossRef]

9. Carr, J.B. Local government autonomy and state reliance on special district governments: A reassessment. Political Res. Q. 2006, 59, 481-492. [CrossRef]

10. Krueger, S.; Bernick, E.M. State rules and local governance choices. Publius J. Fed. 2010, 40, 697-718. [CrossRef]

11. Youm, J.; Feiock, R.C. Interlocal collaboration and local climate protection. Local Gov. Stud. 2019, 45, 777-802. [CrossRef]

12. Svara, J.H.; Watt, T.C.; Jang, H.S. How are US cities doing sustainability? Who is getting on the sustainability train, and why? Cityscape 2013, 15, 9-44.

13. ICMA. Local Government Sustainability Policies and Programs, 2010; International City/County Management Association (ICMA): Washington, DC, USA, 2010. 
14. Feiock, R.C.; Tavares, A.F.; Lubell, M. Policy instrument choices for growth management and land use regulation. Policy Stud. J. 2008, 36, 461-480. [CrossRef]

15. Wood, B.D.; Bohte, J. Political transaction costs and the politics of administrative design. J. Politics 2004, 66, 176-202. [CrossRef]

16. North, D.C. Institutions, Institutional Change and Economic Performance; Cambridge University Press: Cambridge, UK, 1990.

17. Smith, S.R.; Grønbjerg, K.A. Scope and theory of government-nonprofit relations. In The Non-Profit Sector: A Research Handbook, 2nd ed.; Yale University: New Haven, CT, USA, 2006; pp. 221-242.

18. Lipsky, M.; Smith, S.R. Nonprofits for Hire: The Welfare State in the Age of Contracting; Harvard University Press: Cambridge, MA, USA, 1993.

19. ACEEE. The 2010 State Energy Efficiency Scorecard; American Council for an Energy-Efficient Economy (ACEEE): Washington, DC, USA, 2010.

20. Fowler, L. Intergovernmental relations and energy policy: What we know and what we still need to learn. State Local Gov. Rev. 2018, 50, 203-212. [CrossRef]

21. Public Benefits Fund. Available online: https://www.c2es.org/document/public-benefit-funds (accessed on 10 October 2020).

22. Gerber, B.J.; Teske, P. Regulatory policymaking in the American states: A review of theories and evidence. Political Res. Q. 2000, 53, 849-886. [CrossRef]

23. Meier, K.J.; Wrinkle, R.D.; Polinard, J. Politics, bureaucracy, and agricultural policy: An alternative view of political control. Am. Politics Q. 1995, 23, 427-460. [CrossRef]

24. Miller, G.J. The political evolution of principal-agent models. Annu. Rev. Political Sci. 2005, 8, 203-225. [CrossRef]

25. Bresler-Gonen, R.; Dowding, K. Shifting and shirking: Political appointments for contracting out services in Israeli local government. Urban Aff. Rev. 2009, 44, 807-831. [CrossRef]

26. Ostrom, E.; Schroeder, L.; Wynne, S. Institutional Incentives and Sustainable Development: Infrastructure Policies in Perspective; Westview Press: Boulder, CO, USA, 1993.

27. Burby, R.J.; May, P.J.; Berke, P.R.; Kaiser, E.J.; Dalton, L.C.; French, S.P. Making Governments Plan: State Experiments in Managing Land Use; JHU Press: Baltimore, MD, USA, 1997.

28. Burby, R.J.; Paterson, R.G. Improving compliance with state environmental regulations. J. Policy Anal. Manag. 1993, 12, 753-772. [CrossRef]

29. Tommasi, M.; Weinschelbaum, F. Centralization vs. decentralization: A principal-agent analysis. J. Public Econ. Theory 2007, 9, 369-389. [CrossRef]

30. Lang, S. Progress in energy-efficiency standards for residential buildings in China. Energy Build. 2004, 36, 1191-1196. [CrossRef]

31. Kostka, G.; Hobbs, W. Local energy efficiency policy implementation in China: Bridging the gap between national priorities and local interests. China Q. 2012, 211, 765-785. [CrossRef]

32. LaRue, A.M.; Cole, N.C.; Turnbull, P.W. What If This Actually Works? Implementing California's Zero Net Energy Goals. In Energy Efficiency: Towards the End of Demand Growth; Academic Press: Cambridge, MA, USA, 2013; pp. $275-304$.

33. Potoski, M.; Prakash, A. The regulation dilemma: Cooperation and conflict in environmental governance. Public Adm. Rev. 2004, 64, 152-163. [CrossRef]

34. Mahmoodi, J.; Prasanna, A.; Hille, S.; Patel, M.K.; Brosch, T. Combining "carrot and stick" to incentivize sustainability in households. Energy Policy 2018, 123, 31-40. [CrossRef]

35. Repetto, R. Economic incentives for sustainable production. Ann. Reg. Sci. 1987, 21, 44-59. [CrossRef]

36. Norton, R.K. Local commitment to state-mandated planning in coastal North Carolina. J. Plan. Educ. Res. 2005, 25, 149-171. [CrossRef]

37. Norton, R.K. More and better local planning: State-mandated local planning in coastal North Carolina. J. Am. Plan. Assoc. 2005, 71, 55-71. [CrossRef]

38. Aroonruengsawat, A.; Auffhammer, M.; Sanstad, A.H. The impact of state level building codes on residential electricity consumption. Energy J. 2012, 33, 31-52. [CrossRef]

39. Banfi, S.; Farsi, M.; Filippini, M.; Jakob, M. Willingness to pay for energy-saving measures in residential buildings. Energy Econ. 2008, 30, 503-516. [CrossRef]

40. Hamilton, D.K.; Miller, D.Y.; Paytas, J. Exploring the horizontal and vertical dimensions of the governing of metropolitan regions. Urban Aff. Rev. 2004, 40, 147-182. [CrossRef]

41. Stephens, G.R. State centralization and the erosion of local autonomy. J. Politics 1974, 36, 44-76. [CrossRef]

42. Zimmerman, J.F. State-Local Relations: A Partnership Approach; ABC-CLIO: Santa Barbara, CA, USA, 1995.

43. Potoski, M. Managing uncertainty through bureaucratic design: Administrative procedures and state air pollution control agencies. J. Public Adm. Res. Theory 1999, 9, 623-640. [CrossRef]

44. Deslatte, A.; Feiock, R.C.; Wassel, K. Urban pressures and innovations: Sustainability commitment in the face of fragmentation and inequality. Rev. Policy Res. 2017, 34, 700-724. [CrossRef]

45. Boyne, G.A.; Meier, K.J.; O’Toole, L.J. Public Service Performance: Perspectives on Measurement and Management; Cambridge University Press: Cambridge, UK, 2006; 295p.

46. Clean Energy Standards: State and Federal Policy Options and Considerations. Available online: https://www.c2es.org/ site/assets/uploads/2019/11/clean-energy-standards-state-and-federal-policy-options-and-considerations.pdf (accessed on 25 October 2020). 
47. Rabe, B.G. States on steroids: The intergovernmental odyssey of American climate policy. Rev. Policy Res. 2008, 25, 105-128. [CrossRef]

48. Sellers, M.; Byers, J.J. County Authority: A State by State Report; National Association of Counties: Washington, DC, USA, 2010.

49. Lubell, M.; Feiock, R.C.; De La Cruz, E.E.R. Local institutions and the politics of urban growth. Am. J. Political Sci. 2009, 53, 649-665. [CrossRef]

50. Eberly, L.E.; Casella, G. Estimating Bayesian credible intervals. J. Stat. Plan. Inference 2003, 112, 115-132. [CrossRef]

51. Feiock, R.C.; West, J.P. Testing competing explanations for policy adoption: Municipal solid waste recycling programs. Political Res. Q. 1993, 46, 399-419. [CrossRef]

52. Wang, X.; Hawkins, C.V.; Lebredo, N.; Berman, E.M. Capacity to sustain sustainability: A study of US cities. Public Adm. Rev. 2012, 72, 841-853. [CrossRef]

53. Nesticò, A.; De Mare, G. Government tools for urban regeneration: The cities plan in Italy. A critical analysis of the results and the proposed alternative. In Proceedings of the International Conference on Computational Science and Its Applications, Guimarães, Portugal, 30 June-3 July 2014; pp. 547-562.

54. Sun, X.; Wang, W.; Pang, J.; Liu, X.; Zhang, M. Study on the evolutionary game of central government and local governments under central environmental supervision system. J. Clean. Prod. 2021, 296, 126574. [CrossRef]

55. Akrofi, M.M.C.; Akanbang, B.A. Integrating sustainable energies into local government plans in Ghana. Sci. Afr. 2021, 12 , e00764. [CrossRef]

56. Tiba, S.; Omri, A. Literature survey on the relationships between energy, environment and economic growth. Renew. Sustain. Energy Rev. 2017, 69, 1129-1146. [CrossRef]

57. AlKhars, M.; Miah, F.; Qudrat-Ullah, H.; Kayal, A. A Systematic Review of the Relationship Between Energy Consumption and Economic Growth in GCC Countries. Sustainability 2020, 12, 3845. [CrossRef] 